\title{
Semioses do Carnaval: a construção de sentidos no projeto estético-criador de Paulo Barros
}

\author{
The Generation of Meaning in Brazilian Carnival by \\ Paulo Barros's Aesthetic-Creator Project
}

Juliana dos Santos Barbosa*

Resumo: No ambiente criativo das agremiações carnavalescas, diferentes linguagens são transmutadas e combinadas para comunicar o enredo da Escola. Este artigo examina o processo de construção de sentido na estética criadora do carnavalesco Paulo Barros. De modo mais específico, analisa a transmutação de formas no processo de criação da alegoria "Onde está Wally”, desenvolvida para o carnaval de 2007 da Unidos do Viradouro, ano em que a Escola abordou os diversos tipos de jogos com o enredo "A Viradouro vira o jogo". As lentes teóricas mobilizadas para esta análise vêm do escopo da Crítica Genética e da Semiótica Peirceana, aporte conceitual a partir do qual acessamos o espetáculo sob uma perspectiva pouco conhecida pela maioria do público: a dos seus bastidores, onde signos textuais e códigos imagéticos desfilam embalados por matrizes sonoras que sugerem gestualidades. São as semioses do carnaval: processos comunicativos geradores de sentido nos desfiles das escolas de samba.

Palavras-chave: Processos criativos. Tradução intersemiótica. Carnaval.

Abstract: At the creative environment of Carnival colleges, different languages are exchanges to communicate the story of the college. This paper exams the process of construction of meanings at Paulo Barros's creator aesthetic, a Brazilian Carnival artistic producer. Specifically, it analyzes the

\footnotetext{
* Mestre (2007) e Doutora (2013) em Estudos da Linguagem pela Universidade Estadual de Londrina (UEL). Docente da Faculdade Pitágoras - Londrina. Contato: jsbcomunicacao@gmail.com.
} 
exchanges in the process of creation on the allegory "Where is Waldo", developed for 2007 Carnival by the college Unidos do Viradouro; that year, this Carnival College talked through several kinds of games with the plot "A Viradouro vira o jogo" ("Viradouro turns the game on"). The theoretical scope comes from Genetic Criticism and Peirce's Semiotics; this contribution lets us access the show by an unknown perspective: its backstage, where textual signs and imagery codes parade followed by tune patterns that suggest gestures. The Carnival generation of meanings is: communicative processes that engender senses in the parades of Samba colleges.

Keywords: Creative processes. Intersemiotic translation. Carnival.

\section{Introdução}

É quarta-feira feira de cinzas. Enquanto foliões, espectadores e trabalhadores responsáveis pelo grande espetáculo manifestam o desejo de descanso, há mentes criadoras a pleno vapor, anunciando possibilidades temáticas para o próximo carnaval. É assim o processo criativo no universo das Escolas de Samba. Embora os desfiles tenham a duração efêmera de pouco mais de uma hora, sua produção artística demanda quase um ano de trabalho, envolvendo comunidades e centenas de pessoas que desenvolvem atividades de pesquisa, criação, confecção de figurinos e alegorias, além de ensaios musicais e coreográficos.

A proposta científica da Crítica Genética é bastante oportuna para investigar esse ambiente, quando aponta suas lentes para o que vem antes da obra pronta, a fim de revelar a arte guardada nos bastidores da criação, ou, poderíamos dizer, a arte do processo criativo. Os estudos genéticos implicam um olhar que priorize a produção artística sobre o produto, que procure desvendar movimentos cognitivos que levaram à construção da obra de arte, revelar procedimentos, suscitando reflexões sobre o que chamamos de estética da criação. Como o artista constrói sua obra? Quais são as tendências de seu projeto criativo? Como se relaciona com os materiais com que trabalha, com o tempo e com o espaço da criação? O que motiva suas escolhas? Estas questões fomentam os estudos genéticos, área do conhecimento que estabelece parâmetros científicos aos estudos sobre o processo de criação artística. 
Em nossa pesquisa de mestrado (BARBOSA, 2007), investigamos o percurso criativo nas escolas de samba sob a ótica da Crítica Genética. Identificamos que os desfiles carnavalescos são espetáculo híbridos, constituídos por diferentes matrizes de linguagem, cuja produção é um contínuo movimento tradutório: um texto vira imagem, que vira som, que se transforma em coreografia. Também analisamos a expressividade linguística de sambas-enredo a partir do referencial teórico da Estilística. O objeto de estudo foi constituído por documentos de processo relativos à produção do desfile do ano de 2007 da Escola de Samba Unidos do Viradouro, à época sob o comando de Paulo Barros.

O carnavalesco, então novato no Grupo Especial do carnaval carioca, tem seu espaço garantido nesta categoria desde então. Seu trabalho ganhou destaque em 2004, quando levou para o desfile da Unidos da Tijuca a alegoria “Criação da vida”, representando o código do DNA. Mais de 200 pessoas compunham a alegoria, em uma espécie de pirâmide humana. O desfile mostrou as grandes descobertas da ciência, e contou com a presença do cientista Roald Hoffman, ganhador do Prêmio Nobel de Química em 1991. Em seu primeiro ano no grupo especial, conquistou o vice-campeonato. Seu estilo, entretanto, dividiu opiniões. Houve quem considerasse um avanço, como o carnavalesco Milton Cunha, que declarou: "a isso se dá o nome de evolução"1. Outros avaliaram com menos entusiasmo: "Você não acha que fere o regulamento ao não colocar adereços nos carros?", questiona na mesma matéria o diretor de carnaval da escola Beija-Flor, Laíla. Entre admiradores e questionadores, muito se falou sobre o carnavalesco no período em que desenvolvíamos a pesquisa de mestrado.

Com um olhar interpretativo sobre sua forma de conduzir a produção do desfile, identificamos aspectos que costumam direcionar sua busca estética, como o uso de materiais inusitados, a tendência à inclusão de movimentos que agregam sentido às alegorias, a exploração de metáforas visuais, entre outros. No ano em que desenvolveu o enredo sobre a história da música, por exemplo, a saia da porta-bandeira representava um disco (CD) que

\footnotetext{
1 “Um pé aqui, outro no futuro". Matéria veiculada em fevereiro de 2005. Disponível em: <www.jbonline.com.br>. Acesso em: 03 mar. 2005.
} 
girou pela avenida sob o comando do mestre-sala, um disque-jóquei com o figurino de ninguém menos que o músico Wolfgang Amadeus Mozart, usando modernos fones de ouvido. Quando o tema do desfile foi o mundo dos jogos, o figurino do casal porta-estandarte foi formado pela saia em forma de roleta, usada pela porta-bandeira, que girou pela avenida, conduzida por um crupiê. Para Panichi e Contani, (2003, p. 101), a "imaginação criativa nasce do interesse do criador em explorar as possibilidades maiores de certas matérias ou realidades. É produto de sua capacidade relacional, ou seja, de efetuar conexões. [...] e mesmo deriva das leituras que o criador é capaz de efetuar".

Os dados coletados para a investigação feita durante o mestrado constituíram um corpus vastíssimo que, além de atender às demandas ao projeto de pesquisa, ofereceram um manancial para futuras investigações. É o que propomos agora, quando revisitamos o processo criativo de Paulo Barros sob o prisma do percurso intersemiótico de produção de sentidos. Visando ampliar o recorte da pesquisa e alcançar outras dimensões do movimento criador do carnavalesco, mobilizamos conceitos da Crítica Genética combinados aos aportes teóricos da Semiótica.

Defende Iasbeck (2011, p. 194), que o método semiótico disponibiliza instrumentos de investigação para todas as ciências, "sem agredir ou contestar os paradigmas de cada uma delas". Pelo contrário, complementa o autor, o resultado dessa parceria "costuma ser a ampliação das possibilidades exploratórias do objeto”. A semiótica, enquanto ciência que se dedica a estudar a produção de sentido, tem nas linguagens seu objeto privilegiado de análise.

Ao usarmos aqui o termo "linguagens", no plural, reforçamos o papel que conferimos à análise semiótica. $\mathrm{O}$ século $\mathrm{XX}$, com o surgimento e desenvolvimento da fotografia, do cinema, da televisão e, contemporaneamente, das convergências possibilitadas pelas tecnologias digitais, chamou à cena a semiótica como ciência de todas as linguagens, não só a tradição verbal e literária, as quais deu primazia a linguística. A semiótica, portanto, é mobilizada aqui como arcabouço analítico mais adequado à análise da comunicação contemporânea, onde imagens, sons, gestos, expressões, interpretações, cores, volumes, cheiros, fazem parte do processo comunicacional e do processo artístico. Podemos dizer que a 
contemporaneidade nos pede uma dimensão semiótica de "leitura", ou seja, de olhar consciente sobre o nosso mundo. No tocante ao desfile carnavalesco, por sua associação com música, coreografias, alegorias em movimento, enredo, a semiótica é necessária ao entendimento do processo criativo, pela natureza organizadora dessa diversidade expressiva.

Os aportes semióticos nos oferecem recursos para identificar as estratégias utilizadas por Paulo Barros para organizar o discurso visual de seus desfiles. Que competências comunicativas estão presentes em sua estética criadora? Como ele combina signos visando a produção de sentido? Sabemos que o processo de comunicação existe em função da produção de sentido, da interação que se estabelece entre os interlocutores. E num processo interativo, não basta que exista um estímulo, a resposta (em amplo sentido) é essencial para configurar a qualidade da relação e, consequentemente, para os sentidos aí produzidos.

Das referências semióticas, a que mais nos importa aqui é a noção peirceana de interpretante, ou resumidamente, numa dimensão onde tudo é signo, não só a linguagem verbal, os interpretantes são as múltiplas representações que mobilizamos para representar os objetos, conceitos e sentimentos a que nos referimos. Para definir um signo, "sonho', por exemplo, podemos usar a imagem de uma névoa, ou de água. O vermelho pode expressar raiva, ou energia, e assim por diante. São interpretantes culturais, que na vida social e na comunicação se combinam e permitem a chamada "semiose ilimitada", ou seja, o uso ilimitado e criativo de interpretantes na comunicação. Diz Umberto Eco que a ideia de interpretante "resolve a semiótica em ciência rigorosa dos fenômenos culturais” (1974, p. 18)

Considerando que o percurso criativo se dá em diferentes linguagens, nossa abordagem está ancorada também nos pressupostos da Tradução Intersemiótica, definida por Plaza (2008) como um tipo de tradução de um sistema de signos para outro. A análise se detém, de forma mais pontual, no percurso gerador de sentido inerente à criação da alegoria “Onde está Wally, elaborada para o carnaval de 2007 da Viradouro, ano em que a Escola explorou o universo dos jogos com o enredo "A Viradouro vira o jogo". Fundada em 1947, na cidade de Niterói (RJ), a Viradouro desfilou na referida cidade por 39 anos e, em 1986, passou a desfilar no carnaval do Rio de 
Janeiro. Ingressou no Grupo Especial ${ }^{2}$ em 1991 e, no ano de 2015, a 12 colocação fez com que retornasse ao Grupo de Acesso, categoria na qual se classificou em $3^{\circ}$ lugar, em 2016.

\section{As Semioses do Carnaval}

Seja pela diversidade da festa, seja pela riqueza cultural de suas manifestações, o carnaval brasileiro é um dos maiores do mundo. As Escolas de Samba do Rio de Janeiro, por sua vez, constituem uma das manifestações mais representativas do carnaval em nosso país. Em seus desfiles, essas agremiações carnavalescas percorrem a Avenida apresentando uma narrativa, uma história com início, meio e fim, representada por signos visuais, verbais, sonoros e gestuais. Esse espetáculo de linguagem sincrética foi definido por Joãosinho Trinta (1933 - 2011) como uma ópera popular. Precursor do processo de verticalização dos desfiles, o carnavalesco também consolidou a presença do luxo nos desfiles. Segundo ele:

O Carnaval é uma ópera, só que popular. A ópera erudita começa com o Libreto; a escola de samba com o enredo. Na erudita há uma orquestra; na escola, bateria. A ópera tem cenários; a escola, carros alegóricos. A ópera possui um corpo de baile que dança, mas não canta; a escola tem passistas que não cantam, mas dizem no pé. A ópera tem coral; e a escola, integrantes das alas, que cantam. Por fim, a ópera tem personagens principais equivalentes aos destaques da escola. Se for contar, são seis aspectos que unem a ópera erudita à popular (CEDRONI, 2004, p. 24).

Os principais elementos de uma escola de samba, segundo Ferreira (2004, p. 368-369) são: as alas, formadas por um conjunto de pessoas usando,

${ }^{2}$ A cidade do Rio de Janeiro tem mais de 50 escolas de samba divididas em diferentes categorias. No Grupo Especial estão as 12 maiores agremiações carnavalescas. As demais escolas pertencem aos chamados Grupos de Acesso, que se subdividem em grupo de acesso A, grupo de acesso B, e assim sucessivamente, até o E, grupo que reúne as agremiações de menor porte. 
em geral, a mesma fantasia; a ala das baianas, composta exclusivamente por mulheres, que usam fantasias caracterizadas por amplas saias rodadas; a bateria, formada um grupo de ritmistas responsáveis pela execução do samba por meio de vários instrumentos de percussão como surdos, cuícas e tamborins; puxador ou intérprete, que é pessoa responsável por cantar o samba-enredo durante o desfile; a comissão de frente é grupo responsável por apresentar o desfile da escola, tendo incorporado características teatrais nos últimos anos; o mestre-sala e a porta-bandeira formam o casal responsável por apresentar o pavilhão (bandeira) da escola com uma coreografia; a rainha da bateria é uma passista ou artista que desfila à frente da bateria das escolas de samba; as alegorias são elementos visuais que representam o enredo da escola, conhecidas também como carros alegóricos ou tripés; os destaques são componentes que, em geral, usam uma fantasia mais luxuosa que as das alas, podendo desfilar no chão ou em uma alegoria.

Em seus desfiles, com transmissão televisiva para todo o mundo, cada escola do grupo especial reúne, em média, 3800 componentes que cruzam a Marquês de Sapucaí sob a coordenação dos diretores de harmonia. Atualmente, as agremiações têm até 80 minutos para desfilar pela Passarela do Samba e, no concurso realizado, os jurados atribuem notas aos seguintes quesitos: bateria, samba-enredo, harmonia, evolução, enredo, conjunto, alegorias e adereços, fantasias, comissão de frente e mestre-sala e portabandeira. "Cada jurado recebe um roteiro completo do desfile de cada uma das escolas que deverá avaliar. Baseando-se nesse roteiro, define a sua nota para um determinado quesito", explica Blass (2007, p. 108).

Quem assiste ao espetáculo nem sempre imagina a riqueza de seus bastidores. A palavra Carnaval traz em seu bojo o sentido de festa, lazer, diversão e alegria, contudo, o período que antecede ao desfile das Escolas envolve pesquisa, criação, planejamento, montagem e ensaios, um trabalho que exige rotina e disciplina. Não se pode desprezar o fato de que "a realização de um desfile de Carnaval está intimamente relacionada com o funcionamento cotidiano de uma escola de samba". Um cotidiano que acontece nos barracões e quadras, onde, durante meses, o desfile é preparado. São várias equipes de profissionais, participando em diferentes momentos deste processo. "Em todos os lugares e em todos momentos transparece a dimensão coletiva de um desfile de carnaval" (BLASS, 2007, p. 25; 109). 
Tudo começa com a definição do enredo e do carnavalesco, ou seja, o tema do desfile e o responsável por desenvolvê-lo, artisticamente. Daí em diante, a maneira mais convencional de se desenvolver o trabalho prevê a elaboração inicial de uma sinopse, uma espécie de narrativa textual que constitui a "espinha dorsal" do desfile, um texto construído por meio de pesquisas bibliográficas e de campo. Sua função é nortear todo o processo de produção do desfile em suas diversas linguagens: a criação de fantasias e alegorias, bem como a concepção das coreografias e do samba-enredo - a trilha sonora do desfile. O carnavalesco deve buscar a coerência entre os diversos elementos e linguagens que compõem o desfile, visando garantir uma boa compreensão do espetáculo por parte da plateia.

Se para a maioria dos carnavalescos e para a tradição das escolas de samba o texto constitui o fio condutor que costura a diversidade de signos, espaços e tempos que constituem os bastidores dos desfiles, Paulo Barros diverge de tal concepção, apontando a imagem como elemento balizador de seu processo criativo:

meu ponto de partido é sempre a imagem [...] para compor o enredo, primeiro escolho as imagens, defino os carros alegóricos, o que vou dividir em setores e as alas, faço a conceituação e, depois de tudo pensado, começo a contar essa história [...] Odeio essa tal de sinopse! (BARROS, 2013, p. 176-177).

Embora os caminhos sejam diferentes, o percurso criativo tem sempre em seu cerne um intrincado diálogo de linguagens que vai do texto à imagem, da imagem ao som, dos sons aos gestos, e vice-versa. Quem vivencia os bastidores das agremiações carnavalescas vê um outro espetáculo, em que signos textuais e códigos imagéticos desfilam embalados por matrizes sonoras que, por sua vez, sugerem gestualidades. São as semioses do carnaval: processos geradores de sentido que instauram a comunicabilidade entre emissores e receptores nos desfiles das escolas de samba.

Toda ideia, todo pensamento tem que ser traduzido numa linguagem que permita a interação comunicativa. Contudo, a representação por meio de um código não é suficiente para garantir a comunicabilidade entre dois interlocutores. Em seus estudos no campo dos signos linguísticos, Jakobson 
(2010, p. 46), define que "para ser eficiente, o ato de fala exige o uso de um código comum por seus participantes". Se não houver um repertório comum ou uma certa equivalência entre os símbolos selecionados pelo remetente e os que o destinatário conhece, a mensagem se torna infrutífera - "mesmo quando atinge o receptor, não o afeta", completa o linguista.

O carnavalesco Paulo Barros preocupa-se em afetar o receptor, seu projeto criativo se fundamenta no olhar do espectador, na reação do destinatário:

Minha aposta é a interação com o público. Quero um espetáculo onde as pessoas não fiquem apenas assistindo a alegorias e alas passando pela Avenida, sentadas em suas arquibancadas ou no conforto de frisas e camarotes. Quero provocar o susto, a surpresa, o grito, o riso, a dança, o aplauso. O desfile é para ser uma brincadeira, um jogo de cena com a plateia. Quando o público vibra, responde, interage, o objetivo do meu trabalho foi atingido (BARROS, 2013, p. 165)

O desenvolvimento de uma estética criadora caracterizada pela busca da interação é resultado da percepção de que os desfiles nem sempre eram compreendidos pelo público. Com a percepção de que algumas fantasias precisavam de manual de instrução, Paulo Barros decidiu se colocar, literalmente, no lugar de quem assiste. Sentou na arquibancada da avenida Marquês de Sapucaí e assistiu aos desfiles. Olhando da plateia, o artista teve a possibilidade de ver com os olhos dos outros, de perceber cada ângulo, de antever o que cada movimento é capaz de provocar. Capturando o olhar de quem assiste ao desfile, o carnavalesco colocou como elemento central de projeto criativo a interatividade. Plaza (2008, p. 52) fala do olhar como produtor dos objetos imediatos do signo:

A percepção visual atua recebendo informações sob a forma de textos, imagens, cores em termos de 'imagens mentais'. O seu registro é feito pela exploração do campo visual, conjugando a percepção global ou simultânea e linear. Contudo, estes aspectos, que permitem a captação da informação visual, podem ser organizados a partir da própria constituição sígnica. Isto é, quando organizamos o signo, estamos 
também organizando a construção do olhar. Assim, o olho não é somente um receptor passivo, mas formador de olhares, formador de Objetos Imediatos da percepção.

Outra peculiaridade inerente à estética criadora de Paulo Barros é o uso de materiais inusitados. Na busca de soluções para seus projetos, ele já criou alegorias feitas com bolinhas de plástico, panelas, talheres, latarias de carros e outros tipos de materiais que, em princípio, não teriam valor estético. "Eu gosto de causar reações, o carro [alegórico] só não pode passar impune", declara (BARROS, 2013, p. 44 a 50). Tais inovações, contudo, estão sempre no contexto temático do desfile, cumprindo a função de comunicar o enredo em cada detalhe. As panelas e talheres, por exemplo, foram usadas para representar o Homem de Lata. Cerca de 12 mil peças de alumínio foram utilizadas na construção do personagem da Terra de Oz. A alegoria, com 9 metros de altura, constituía uma perfeita combinação de formas e sentidos, feita sob o eixo paradigmático - tipo de associação baseada na semelhança entre signos (PIGNATARI, 2004). Se fosse observada a partir da linguística de orientação saussureana, poderíamos descrever a construção da alegoria como uma simbiose entre significante e significado.

Ao mesmo tempo em que o carnavalesco propõe inovações na construção das formas diferenciadas, ele busca conteúdos que estejam no imaginário de todos, dialogando a partir de campos culturais que facilitam a comunicação. "Eu uso referências que estão no inconsciente coletivo. Uso essas imagens em cenas que sei que as pessoas vão reconhecer, identificar imediatamente". A intenção do carnavalesco é "proporcionar sentimentos que façam a conexão entre o que você quer significar e o outro" (BARROS, 2013, p. 179-180). Quando constrói o discurso visual do desfile, o artista lança mão de imagens conhecidas e as transforma em novidade deslocandoas de lugar, inserindo-as em outro contexto e provocando surpresa e espanto a partir do que é compreensível e decodificável.

A questão do repertório comum entre os interlocutores é citada por Jakobson como fator essencial de comunicabilidade. Em convergência com este pensamento, vamos encontrar tanto em Peirce quanto em Bakhtin, a concepção da linguagem como algo necessariamente social. Em nossa reflexão sobre a estética criadora de Paulo Barros fica evidente a competência 
comunicativa do carnavalesco, que pensa o desfile a partir o repertório cultural do público, consciente de que a linguagem não é uma propriedade individual, mas se constituiu por meio da construção coletiva de sentidos. Combinando referências compartilhadas com informações inusitadas, as obras visuais de Barros, especialmente as alegorias, evocam reconhecimento e provocam surpresa no público.

\section{A Transmutação de Formas no Processo de Produção de Sentidos da Alegoria “Onde está Wally?”}

Logo após o carnaval de 2006, a imprensa anunciou que Paulo Barros deixaria a Unidos da Tijuca para ingressar como carnavalesco na Unidos do Viradouro, a convite do presidente da agremiação, Marco Lira. Após um mês em seu novo posto, anunciou, em entrevista ao site Tamborins, que o enredo da escola para o próximo ano seria "A Viradouro vira o jogo", declarando-se bastante entusiasmado com a possibilidade de trabalhar com o universo dos jogos, pelo bom retorno visual do tema. "É plasticamente muito bom, e oferece uma gama de possibilidades pela variedade e tipos de jogos. Também é um assunto que está na vida de todo mundo, o público tem familiaridade com o tema" (BARROS, 2006a).

O processo de pesquisa para concepção do desfile começou logo em seguida. Uma viagem a Las Vegas, a capital mundial do entretenimento, onde se joga 24 horas por dia, foi uma das primeiras fontes de inspiração para conceber o carnaval daquele ano. Simultaneamente, uma equipe pesquisava sobre as mais variadas modalidades de jogos existentes em todo o mundo, tendo como principais instrumentos a Internet e livros. Em seu retorno, uma das primeiras propostas de Paulo Barros para o carnaval de 2007, divulgadas pelo site Tamborins, foi a de que o público não seria mero espectador dos desfiles das escolas de samba:

vou fazer com que o público interaja com a Viradouro durante o desfile. A escola vai passar e as pessoas vão ter que descobrir onde está Wally. [...]. Vai ser uma grande brincadeira e eu vou fazer o público se divertir. Vai ficar todo mundo procurando o Wally. (BARROS, 2006b) 
O desfile daquele ano foi dividido em sete setores: o primeiro mostrava a partida de um jogo de tabuleiro e um cassino; o segundo abordava diversos jogos de cartas; o terceiro setor trazia jogos de raciocínio e estratégia, como o jogo da velha, dama e xadrez; o quarto setor mostrava jogos de construir, como dominó e lego; no quinto setor, jogos de adrenalina, que causam euforia, como vídeo game e pinball; o sexto setor foi dedicado a jogos de passatempo, como detetive, cubo mágico e Onde está Wally?; e por fim, o sétimo setor trazia jogos de competição como tiro ao alvo, futebol e jogos olímpicos.

Em maio de 2006, em entrevista concedida para nossa pesquisa de mestrado, Paulo Barros afirmou que apesar de reconhecer a importância dessa imersão no universo dos jogos, proporcionada pela viagem e pelas pesquisas, sua principal fonte de inspiração são imagens que fazem parte do repertório cultural das pessoas. "Procuro pegar um elemento conhecido, pode ser um dado, por exemplo, e dar a ele um movimento ou uma forma diferente" (BARROS, 2006, p. 72) Em nossa visita ao barracão da escola, realizada no mês seguinte, identificamos que vários croquis e algumas maquetes de carros alegóricos já haviam sido elaborados, mesmo sem a conclusão do texto do enredo. Diante dessa constatação, deduzimos à época que o artista "ao que nos parece, vislumbra primeiramente as possibilidades de se comunicar com o público por meio da imagem para, a partir daí, fundamentar teoricamente a ideia dentro do enredo". Posteriormente, alguns de seus depoimentos no livro "Paulo Barros sem segredo", publicado em 2013 e já citado em parágrafos anteriores, confirmaram nossa hipótese.

O croqui da alegoria “Onde está Wally?" estava entre os materiais afixados em um painel no barracão da escola. Os protótipos de alegorias e figurinos nos foram apresentados pelo desenhista que assessorava o carnavalesco naquele ano (na Figura 1, o croqui da alegoria pode ser observado no canto inferior direito). Logo em seguida, visualizamos na mesa de trabalho do carnavalesco, dois exemplares do livro-jogo de origem inglesa. 


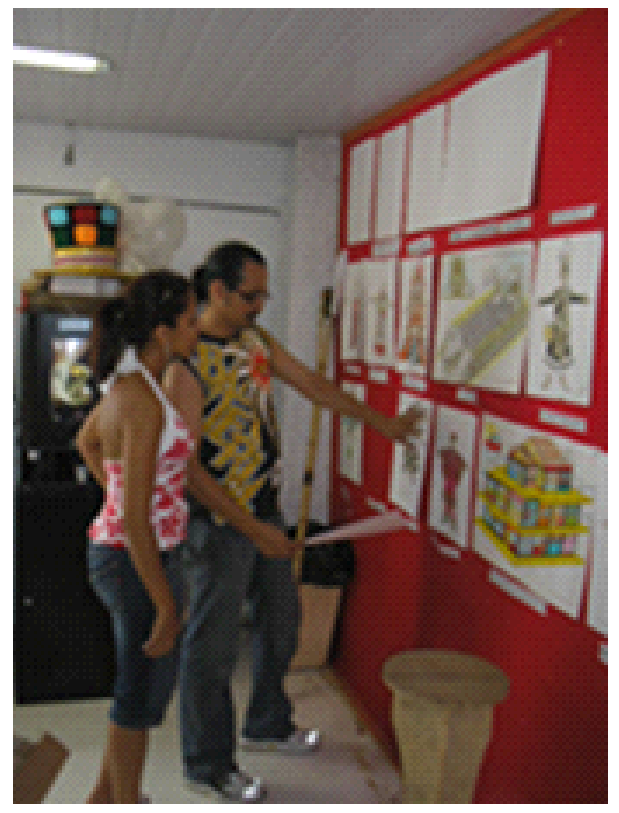

Fonte: Acervo pessoal da pesquisadora.

Figura 1 - Visita ao barracão

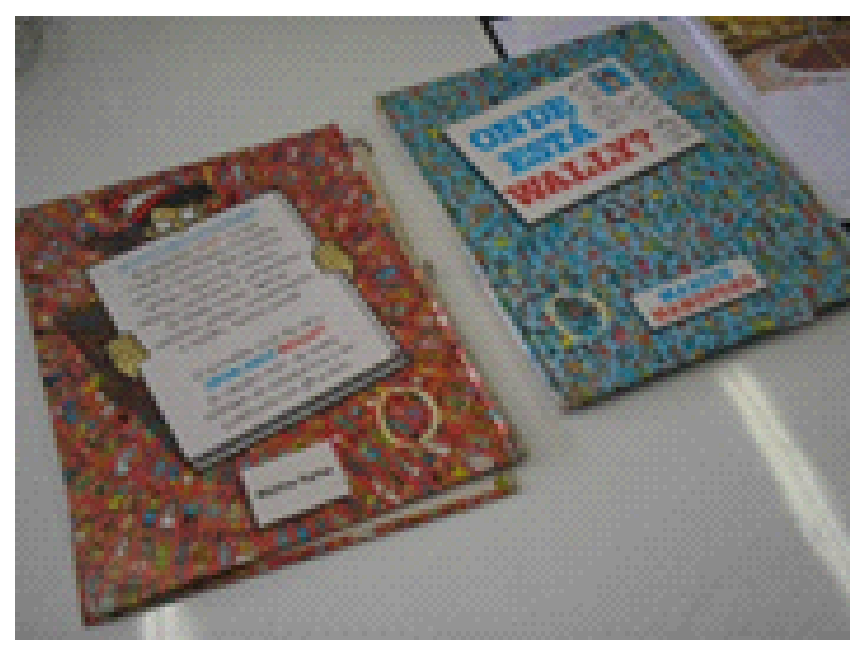

Fonte: Acervo pessoal da pesquisadora.

Figura 2 - Jogos sobre a mesa de trabalho do carnavalesco 
O jogo é uma série de livros infanto-juvenis, criada pelo ilustrador britânico Martin Handfor. Com ilustrações e pequenos textos, a série foi lançada em 1987 e deu origem a uma série animada, uma tira de jornal e jogos eletrônicos. Em 2014, foi lançada a versão online do jogo, que consiste em um sujeito que vive viajando, sempre trajando blusa listrada, calça azul, gorro vermelho e branco e óculos. Bolsa, máquina fotográfica e bengala são acessórios que normalmente o acompanham. Wally vive se perdendo nos diversos lugares para onde vai. Esses locais sempre têm milhares de pessoas em situações as mais variadas, e o desafio do jogador é encontrá-lo no meio de todas essas figuras. Os livros têm temas específicos e, em cada página, cenários diferentes com multidões. Embora o objetivo principal da brincadeira seja encontrar o personagem, no alto da página estão relacionados alguns objetos que também foram perdidos e devem ser procurados.

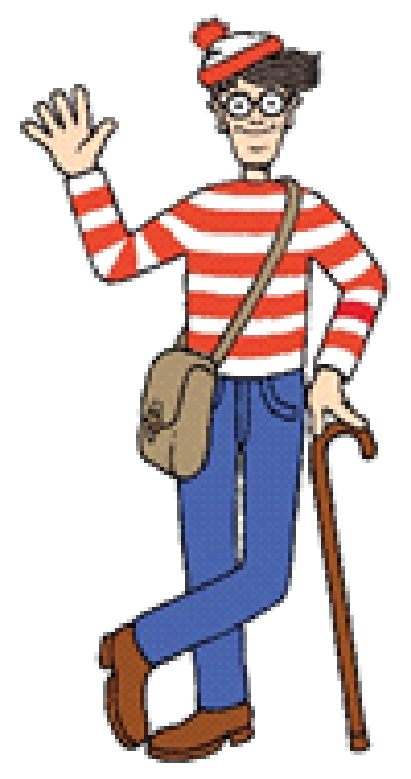

Fonte: <http://metro.co.uk/>

Figura 3 - Wally 
A seguir descrevemos, parcial e retrospectivamente, o percurso criativo da alegoria “Onde está Wally?”. Parcialmente, porque seria impraticável capturar cada pensamento, cada operação cognitiva que ocorre quando o artista está criando. A proposta dos estudos da criação artística não é revelar os mistérios da criação, mas valorizar o processo de construção da obra, como um caminho de busca de soluções, de pesquisa, de experimentações e de inteligência. Como definem Panichi e Contani (2003, p. 147), "quando se está diante de um produto considerado acabado, não se tem a exata dimensão do que significou produzi-lo. É nos bastidores da execução de uma obra que se podem encontrar recursos de natureza cognitiva"

Neste sentido, a proposta consiste em identificar estratégias mobilizadas por Paulo Barros para reproduzir na Passarela do Samba os efeitos de sentido do jogo original. Analisamos o percurso intersemiótico que marcou a tradução entre linguagem utilizada para veicular o conteúdo no material gráfico e a usada para transmitir o mesmo conteúdo, com equivalência semiótica, na alegoria carnavalesca. De que forma os signos foram transmutados e combinados para que o público da Sapucaí ficasse procurando o Wally durante o desfile da escola, da mesma forma que os jogadores ficam à procura do personagem diante do livro?

A metodologia de pesquisa da crítica genética prevê o acesso aos chamados documentos de processo. São rascunhos, esboços, maquetes, primeiras versões e outros tipos de registros usados pelo artista, que deixam pelo caminho, vestígios de seu pensamento em plena criação. Os dois documentos de processo aos quais tivemos acesso para subsidiar nossa investigação foram os livros utilizados como referência (Figura 4) e o croqui do carro alegórico (Figura 5): 


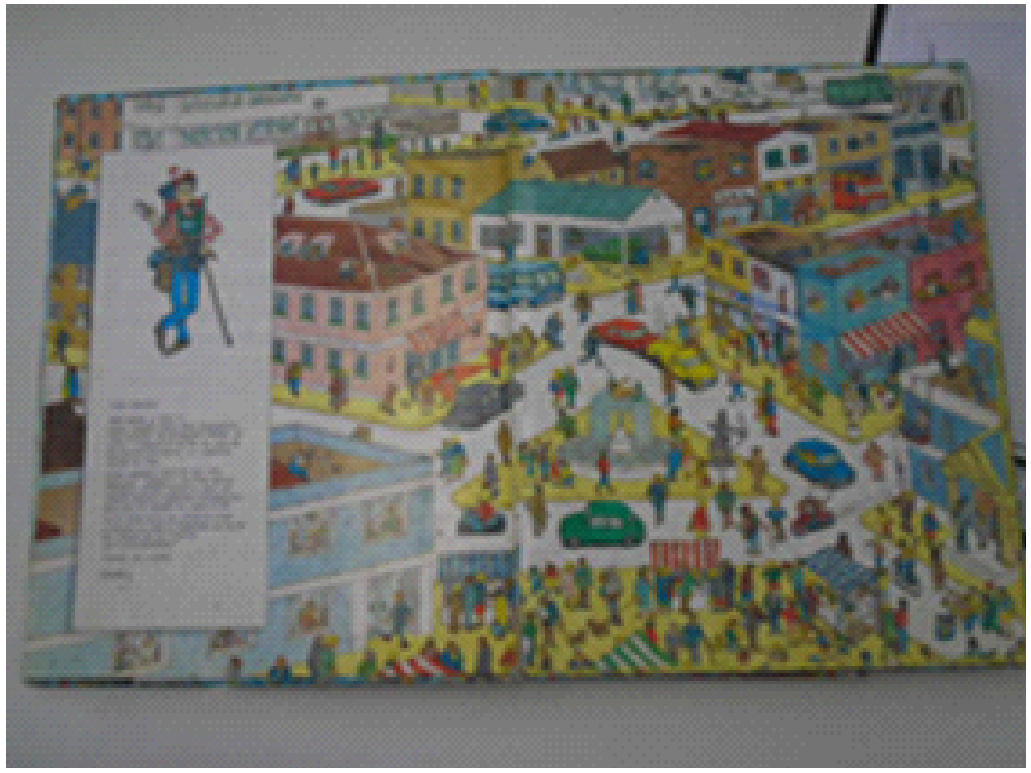

Fonte: Acervo da pesquisadora.

Figura 4 - Jogo do livro "Onde está Wally?”

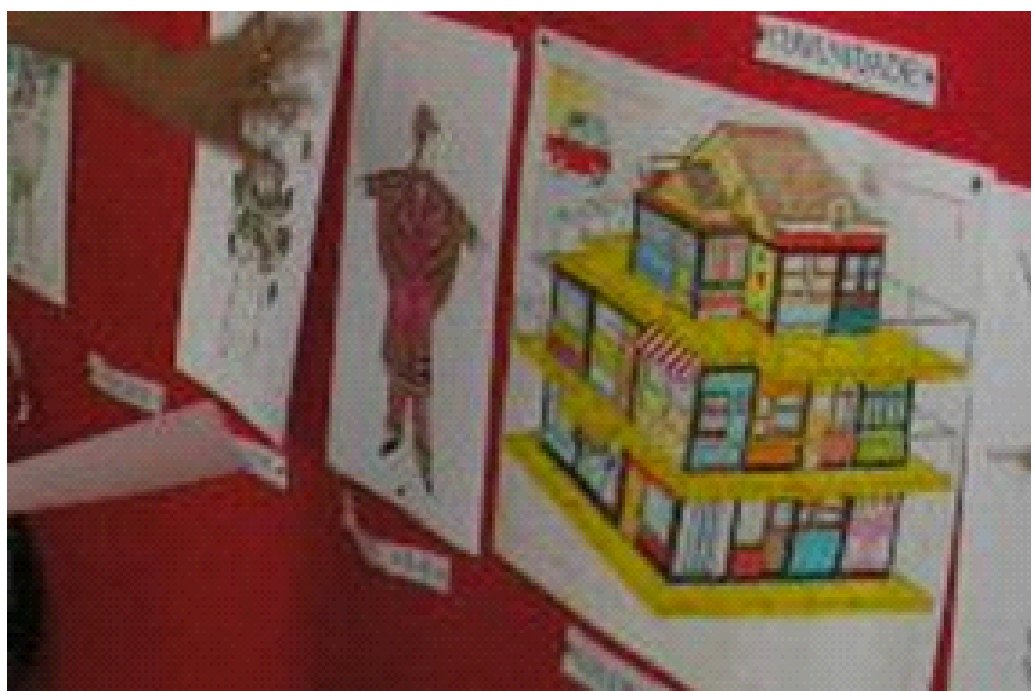

Fonte: Acervo da pesquisadora.

Figura 5 - Croqui da alegoria de Wally 
No livro, a ilustração retrata um grande número de pessoas circulando em ruas bastante movimentadas, com casas, comércios e alguns carros. O colorido marcante prioriza cores primárias e o amarelo aparece em destaque. Essa cor, aliás, aparece de forma predominante em vários livros e jogos da série. Um pequeno texto à esquerda da página orienta o leitor sobre o que deve procurar na imagem. Olhando comparativamente a obra original e o projeto gráfico da alegoria, encontramos pontos de convergência e elementos de adaptação.

Entre as semelhanças mantidas pelo movimento tradutório, o croqui representa uma construção arquitetônica típica do jogo, matizada com cores primárias, evidenciando também o amarelo. No tocante às mudanças, há uma alteração de perspectiva que dá à alegoria uma dimensão predominantemente vertical, em contraposição ao livro, que explora com mais ênfase a dimensão horizontal em suas representações visuais. Ao invés de inúmeras construções espalhadas no cenário, o carro alegórico explora essa diversidade arquitetônica em 3 andares, cada um com 4 faces, oferecendo 12 ângulos diferentes de visão. Em cada andar, a grande variação de cores evoca os sentidos de diversidade e quantidade, contribuindo com a convergência semiótica entre as duas versões. Outros pontos divergentes que identificamos foram as ausências, no projeto da alegoria, de figuras humanas, de texto verbal e de veículos automotores.

Se os pontos de semelhança entre as duas versões garantiriam que o público identificasse a alegoria enquanto signo icônico jogo, a alteração de alguns elementos respondia a especificidades do código carnavalesco e a aspectos da estética criadora de Paulo Barros. Esclarece Plaza (2008, p. 30) que, "numa tradução intersemiótica, os signos empregados têm tendência a formar novos objetos imediatos, novos sentidos e novas estruturas que, pela sua própria característica diferencial, tendem a se desvincular do original". Em outras palavras, a escolha de um sistema de signos induz a caminhos inerentes à sua estrutura, pois, a tradução de uma linguagem para outra não visa somente à representação de uma realidade ou conteúdo existente, mas sim à criação de novas realidades, de novos conteúdos.

No que se refere ao código dos desfiles, a diferença dimensional entre o objeto representado e o seu signo atende a questões de espaço e perspectiva. O sambódromo - com seus 13 metros de largura e 700 metros de extensão - não é um espaço adequado para comportar uma alegoria com dimensões 
laterais proporcionais na horizontal. Além disso, cada escola leva, em média, 7 alegorias para o desfile. Quando falamos de perspectiva, nos reportamos à posição do espectador nas arquibancadas. Com a construção da Marquês de Sapucaí, em 1984, os desfiles das escolas de samba, que antes tinham as ruas como passarela, passaram por mudanças. O carnavalesco Joãosinho Trinta está entre os pioneiros do movimento estético que fez com que as alegorias crescessem em altura, e Paulo Barros, como já afirmamos, concebe o desfile a partir dos olhos de quem o assiste. Daí a verticalização como resultado do movimento tradutório no percurso criador da alegoria de Wally.

Considerando a estética criadora de Barros, a ausência de possíveis bonecos no croqui, representando o contingente humano presente no cenário do jogo, não surpreende. Embora as figuras humanas não estivessem representadas no croqui, as sacadas projetadas em todos os andares davam indícios de que o carro traria uma das principais marcas de seu estilo: alegorias humanas coreografadas, que geram imagens em movimento. Na Sapucaí, durante o desfile, lá estava Wally (Figura 6) de blusa listrada, gorro e óculos, "perdido" no meio da multidão e sendo procurado pelo público.

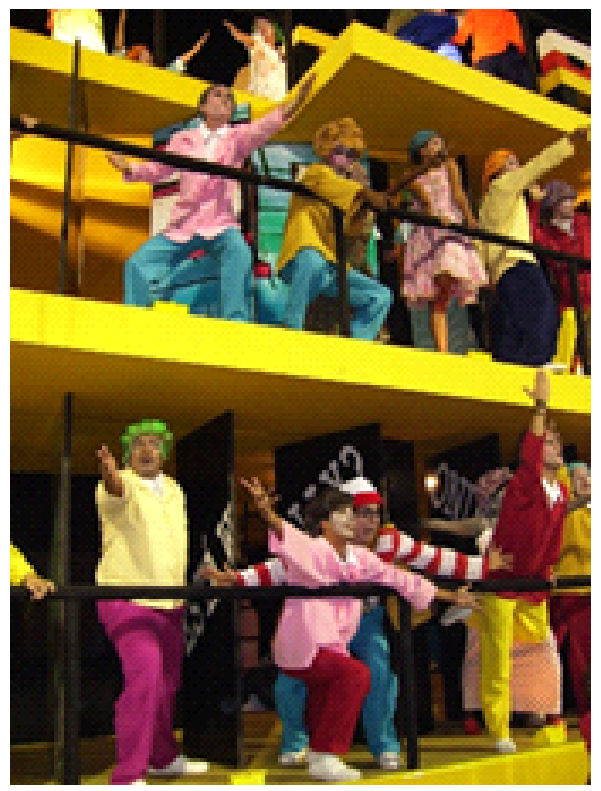

Fonte: Acervo da pesquisadora.

Figura 6 - Alegoria de Wally no desfile 
Durante o desfile, identificamos que os signos verbais também entraram no jogo. Ao contrário do que imaginávamos quando observamos o croqui, o carnavalesco utilizou a linguagem verbal para a construção de sentido nesta alegoria. As portas da construção arquitetônica eram giratórias: de um lado, eram multicoloridas e, do outro, estampavam o nome do jogo, cumprindo um papel de legendas que aumentam a probabilidade de compreensão por parte do espectador (Figura 7). O componente que representou Wally movimentava-se por toda a alegoria de 3 andares durante o desfile, aparecendo a cada momento, em uma das portas. Portas se abriam e fechavam, alterando entre o lado colorido e o lado que trazia "a pergunta que provocava a plateia: Onde está Wally?” (BARROS, 2013, p. 166).

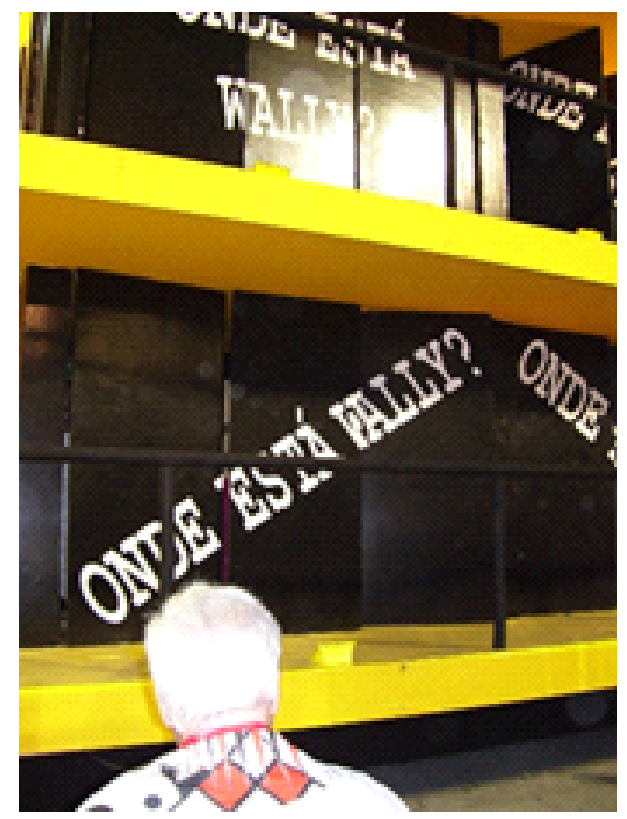

Fonte: Acervo da pesquisadora.

Figura 7 - Detalhe das portas com legenda

Os demais integrantes que dividiam o carro com Wally também se movimentavam e interagiam com o público, e a letra do samba-enredo 
também contribui para a construção de sentido do desfile, fazendo alusão, nas linhas 26 e 27 da composição, ao jogo em análise: "Quebrar a cabeça pra encontrar / achar você no meio dessa multidão". Para além do que chamamos de tradução, o que analisamos é um processo de transcriação, que exige sensibilidade, criatividade e competência comunicativa. Presenciamos o desfile e pudemos conferir de perto a reação das pessoas que, quando o viam, apontavam e manifestavam-se: "Lá está ele, eu vi o Wally". Comprovamos que a interação com os espectadores, planejada pelo carnavalesco na concepção do desfile, se concretizou na avenida.

\section{Conclusão}

Na história do desfile de carnaval das escolas de samba do Rio de Janeiro, podemos identificar fases onde se acentuavam certas características estéticas e artísticas. Num primeiro momento, havia a primazia do samba. Os foliões das escolas, suas alas e seus passistas sambavam na avenida, "carregando" a composição, o ritmo e as cores da escola. "Brincavam o carnaval na avenida", como se diz em referência a esse período. O crescimento do carnaval carioca como grande espetáculo, que passou a ser anunciado como "o maior carnaval da terra", amplificou a imponência das alegorias e o cuidado com as fantasias. Mas durante algum tempo as alegorias e fantasias ainda acompanhavam o enredo como elementos simbolizadores de sua temática; eram bastante fixos, pictóricos.

A partir de Joãosinho Trinta, adentram a Avenida elementos de uma narrativa operística, ampliando as dimensões (em sentido espacial e de conteúdo artístico) das alegorias e fantasias. Em Paulo Barros, o desfile vai ganhar um contorno de narrativa visual mais complexa. Sem deixar de seguir a narrativa do enredo, os carros alegóricos e as fantasias das alas passam a ter uma complexidade ilustrativa e evocativa de diálogos com a cultura popular e a cultura pop.

Podemos identificar, no exemplo da criação do carro alegórico "Onde está Wally”, a aplicação destes elementos do diálogo de referências com o público e do misto de identificação e espanto (surpresa) que Paulo Barros leva para a Sapucaí. Com ele, o desfile se torna mais teatralizado e interativo: torna-se mais operístico, portanto, e passa a influenciar os desfiles carnavalescos. 
Abordar o processo de criação de um carnavalesco tão dinâmico e marcante abre perspectivas importantes para a crítica genética, tanto para compreender a dinâmica criativa em dimensão semiótica (trabalhando múltiplas linguagens), quanto para compreender as possibilidades comunicativas no terreno da arte.

É um dilema da contemporaneidade a relação da arte com o público. Como dialogar sem empobrecer? Como interagir as técnicas e tecnologias com o fazer artístico? Como renovar e transcender, sem perder a força popular e a tradição? Todos esses elementos podem encontrar respostas interessantes na pesquisa do processo criativo desse carnavalesco. É a janela que tentamos abrir neste artigo, analisando uma de suas criações artísticas.

\section{Referências}

BARROS, P. Paulo Barros sem segredos: estética, inovação e criatividade. Rio de Janeiro: Casa da Palavra, 2013.

BARROS, P. Esquentando os tamborins. Disponível em:

$<$ www.tamborins.com.br>. Acesso em: 10 mar. 2006a.

BARROS, P. Esquentando os tamborins. Disponível em:

<www.tamborins.com.br>. Acesso em: 27 abr. 2006b.

BARBOSA, J. dos S. A transmutação de formas e o jogo de linguagens no processo de criação no carnaval 2007: a Viradouro vira o Jogo. 2007. Dissertação (Mestrado em Estudos da Linguagem) - Universidade Estadual de Londrina, Londrina.

BLASS, L. M. da S. Desfile na avenida, trabalho na escola de samba: a dupla face do carnaval. São Paulo: Anablume, 2007.

CEDRONI, G. Joãosinho 70. Revista Trip, a. 17, n. 119, p. 18-26, fev. 2004.

IASBECK, L. C. A. Método Semiótico. In: DUARTE, J.; BARROS, A. (Org.). Métodos e técnicas de pesquisa em comunicação. 2. ed. São Paulo: Atlas, 2011. 
ECO, U. As formas do conteúdo. São Paulo: Perspectiva, 1974.

JAKOBSON, R. Linguística e comunicação. 22. ed. São Paulo: Cultrix, 2010.

PANICHI, E. R. P.; CONTANI, M. L. Pedro Nava e a construção do texto. Londrina: EDUEL; São Paulo: Ateliê Editorial, 2003.

PIGNATARI, D. O que é comunicação poética. 8. ed. Cotia, SP: Ateliê Editorial, 2004.

PLAZA, J. Tradução intersemiótica. São Paulo: Perspectiva, 2008.

Enviado em: 15/11/2016 Aceito em: 17/12/2016 